\title{
Morphological Patterns of a Hymenopteran Gall on the Leaflets of Caryocar brasiliense Camb. (Caryocaraceae)
}

\author{
Ana Carolina Ribeiro de Castro ${ }^{1}$, Germano Leão Demolin Leite ${ }^{2}$, Denis Coelho de Oliveira ${ }^{3}$, \\ Rosy Mary dos Santos Isaias ${ }^{1}$ \\ ${ }^{1}$ Departamento de Botânica, Universidade Federal de Minas Gerais (UFMG), Belo Horizonte, Brasil; ${ }^{2}$ Instituto de Ciências Agrárias, \\ Universidade Federal de Minas Gerais (UFMG), Montes Claros, Brasil; ${ }^{3}$ Instituto de Biologia, Universidade Federal de Uberlândia \\ (UFU), Uberlândia, Brasil. \\ Email: rosy@icb.ufmg.br
}

Received April 24 $4^{\text {th }}, 2012$; revised May 22 ${ }^{\text {nd }}, 2012$; accepted May $31^{\text {st }}, 2012$

\begin{abstract}
Anatomical studies in the leaflet globoid galls of Caryocar brasiliense, the "pequi", aimed to answer how oviposition and the feeding behavior of the galling herbivores altered the morphogenetical patterns of the host plant. C. brasiliense globoid gall was $(1.28 \pm 0.20) \mathrm{mm} \times(0.90 \pm 0.25) \mathrm{mm}$, with hairy surface; it is sessile and projected to the abaxial surface. Young galls were red while the mature ones were green. Preferentially, they were formed next to leaf margin and possessed one larval chamber containing a single galling specimen. Gall epidermis was uniseriate, with thicker cuticle and more hairy. In some spots, epidermis was substituted by periderm, which indicated the expression of a character usually absent in the leaf laminas. Morphological and anatomical features of these gall morphotype, such as its position in leaf lamina, the fact of being truly closed galls, with typical nutritive tissue involved by sclerenchyma, made them next to the pattern proposed for galls induced by some Hymenoptera.
\end{abstract}

Keywords: Gall Anatomy; Hymenoptera; Morphogenesis; Pequi

\section{Introduction}

Galls are abnormal growths induced by viruses, bacteria, fungi, nematodes, mites and insects on a wide variety of host plants. As they cause damages to the development of their host, they may occupy an important place in plant pathology [1]. Gall structures vary enormously from simple masses of parenchyma cells to a set of highly specialized and organized tissues [2] which can be absent in the host plant organs [3]. However, this structure have a modern definition proposed by Raman [4], namely, they are structures induced by insects and generally are symmetrical in form. The differentiation of specialized tissues is a direct result of hyperplasia, hypertrophy and cell redifferentiation, as well as of cell collapse or insect feeding, the main gall inductive processes [5]. During gall formation, several alterations in epidermis, parenchyma, xylem and phloem cells take place [6]. Also, periderm and new vascular bundles differentiation [7-9], cuticle thickness, increase in number of non glandular trichomes, crystals and sclereids appearance, changes in mesophyll cell shapes [7,10-14], and the formation of a nutritive tissue [7,15-19] are some of the most common alterations observed during the develop- ment of gall structure.

When induced in plants of economical importance, galls may be tools for biological control. Nevertheless, the first step of studying these galls must be the elucidation of the morphogenetical effects of the parasitic activity on host tissues. This kind of approach can basically reveal how the changes in plant development occur. Further, according to Mani [6], the basic character of a gall is not either its inducing organism or its abnormal structure, but how the cells next to the gall site escape their normal morphogenesis and assume a new pattern.

Among several galls inventory at the Neotropical region [20-24], the family Caryocaraceae does not appear, which can be due to its low diversity, for this is represented only by two genera (Caryocar and Anthodiscus) and 16 species $[25,26]$. The occurrence of several morphotypes of insect galls in leaves of $C$. brasiliense has been already reported in literature. These galls have been attributed to Hymenoptera [27-29], Hemiptera: Diaspididae [30] and Diptera: Cecidomyiidae [31]. Even though there are no reports of reduction in the production of pequi (Caryocar brasiliense) due to the infestation by galling insects, it is a potential that should be studied. 
The leaves of $C$. brasiliense present dense hair surface, a physical barrier that galling insect surpass, probably due to a matter of size, obtaining success in oviposition. The leaflet globoid gall is induced by a Hymenoptera: Eurytomidae [27,29] and the current study aimed to verify the influences of the gall inducer site of oviposition and feeding behavior on the morphogenesis of its host leaflets. Thus, comparative analysis of leaflets and gall development may indicate the cecidogenic field direction, preferential site for oviposition in leaflet lamina and, mainly, the feeding behavior of the gall inducer.

\section{Methodology}

\subsection{Plant Material Collection}

Non galled leaflets and gall samples were collected between March 2005 and March 2006, in three plants of $C$. brasiliense at the Núcleo de Ciências Agrárias da Universidade Federal de Minas Gerais (NCA/UFMG), Montes Claros, Minas Gerais (4350'26.8"W, $\left.16^{\circ} 40^{\prime} 54.5^{\prime \prime} \mathrm{S}\right)$. Healthy and galled leaves were removed, put in plastic bags and sent to Campus Pampulha of UFMG, in Belo Horizonte, Minas Gerais, where the studies were accomplished.

\subsection{Leaf and Gall Anatomy}

The anatomical studies of non galled leaflets (NG), healthy portion of galled leaflets (HGL) and galls (GL) were performed in fresh and fixed in FAA samples [31]. Transverse sections of leaf lamina, midrib, margin, and longitudinal sections of galls were submitted to permanent and semi-permanent preparations. The sections were clarified in $10 \%$ sodium hypochlorite [32], and washed in distilled water. Safranin and astrablue were used for staining [33] and the laminas were mounted in Kaiser's jelly glycerin [31]. Permanent preparations $(12 \mu \mathrm{m})$ were obtained by Paraplast ${ }^{\circledR}$ inclusion [33] after dehydration in n-buthyl series [31]. The presence of crystals was analyzed with polarizing filters. For epidermis detachment, fragments $\left(1 \mathrm{~cm}^{2}\right)$ of NG, HGL and GL were treated with $50 \%$ sodium hypoclorite at $50^{\circ} \mathrm{C}$, washed in distilled water, and stained with $1 \%$ safranin in ethanol $95^{\circ}$ GL [31]. The epidermal peels were mounted in Kaiser's jelly glycerin [31]. Fragments were clarified in 5\% sodium hydroxide at $37^{\circ} \mathrm{C}$, washed in distilled water, immersed in chloral 1.6:1 (p/v) until completely translucent. The fragments were washed, immersed in ethanol $70 \%$, and stained in $1 \%$ safranin in $50 \%$ ethanol [33]. The fragments were mounted in Kaiser's jelly glycerin [31]. Internervural and vascular bundles areas were calculated by capturing the images in three fields for fragment with the aid of a Motic ${ }^{\circledR}$ digital camera, and ana- lyzing with the graphic program EasyQuantify ${ }^{\circledR}$.

\subsection{Morphometric Analysis}

The external (height and width) and internal measurements (height and width of the chamber) of the galls (GL) $(n=20)$ were obtained from histological sections, using an optical microscope Olympus $\mathrm{CH} 30$ equipped with micrometric eye piece. Gall position in leaflet lamina (n = 390): transverse (margin, center and on midrib) and longitudinal (apex, medium, and base) (Figures 1(a), (b)) were registered. Numerical data were submitted to an ANOVA, followed by Tukey's test ( $\mathrm{p} \leq 0.5)$ using JUMP 5.0 software (Sass Institute Inc. 2002, the statistical discovery software)

\section{Results}

\subsection{General Aspects}

General aspects. Caryocar brasiliense Camb. is a perennial tree, with green-dark trifoliolated leaves on the adaxial surface and light-green in the abaxial surface. Healthy leaflets are densely hairy, with ribs very prominent to the abaxial surface. The galls induced by a Hymenoptera are round, $(1.28 \pm 0.20) \mathrm{mm} \times(0.90 \pm 0.25)$ $\mathrm{mm}$, with hairy surface (Figure 1(c)), sessile, projected to the abaxial surface. Red when young, green at maturity (Figure 1(c)), and brown in senescence (Figure 1(d)). Galls can be grouped (Figure 1(c)), or rarely isolated (simple galls). They are most frequently found in leaflet margins (Figure 1(c)), and never over the larger ribs. It always has one larval chamber (Figure 1(e)) and a single galling insect, whose body almost occupies the entire chamber (Figure 1(f)). The galls concentrate mainly on leaflet medium and basal position. The medium leaflet site presented the smaller percentage of area occupied with ribs when compared to the other leaflet sites. The vascularization of apical and basal sites does not differ significantly amongst themselves (Figure 1(g)).

\subsection{Anatomical Features of Non Galled Leaflets (NG) and Healthy Portions of Galled Leaflets (HGL)}

Either in NG or in the HGL, the dermal system is constituted of uniseriate epidermis, with squared to rectangular cells (Figure 2(a)), smaller in the abaxial surface and next to the leaflet margin (Figure 2(b)). The cuticle is thick and striate, more prominent to the abaxial surface. In frontal view, the epidermal cells are polygonal with straight anticlinal walls on the adaxial leaflet surface (Figure 2(d)) and slightly curved on the abaxial surface. The stomata occur exclusively on the abaxial surface, at the same level of the ordinary cells, with less thick cuticle, 

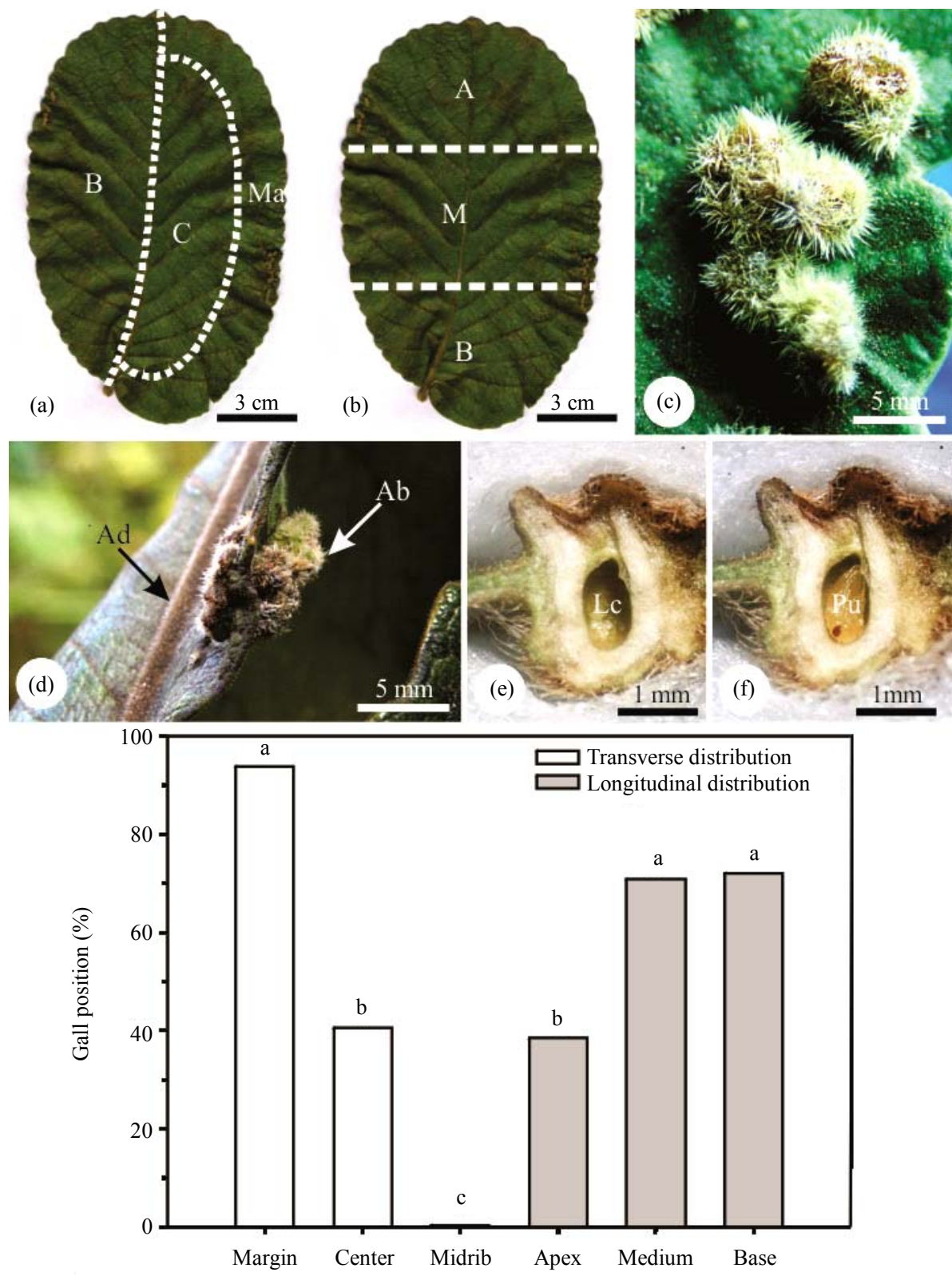

(g)

Leaf region

Figure 1. Relative position of the galls on the leaflets of Caryocar brasiliense (a), (b). Detail of grouped galls on the abaxial leaflet surface (c). Detail of galls on the margin of a leaflet (d). Longitudinal sections of the galls with a central larval chamber and a pupa of the gall inducer (e), (f). Distribution of the galls on the leaflets of Caryocar brasiliense (g). Averages followed by the same letter, within the same group, do not differ by the Tukey test $(p<0.01)$.

and reduced substomatic chambers. Non glandular trichomes (Figure 2(c)) are longer and more abundant in the abaxial surface.

The mesophyll is dorsiventral, with 2 - 3 layered palisade parenchyma, 2 - 3 layered lacunous parenchyma with little conspicuous intercellular spaces (Figure 2(a)). At the leaflet margin, the parenchymatic cells are isodiametric, colorless, with a large vacuole and thin cell walls (Figure 2(b)). Crystals are observed all over the mesophyll (Figure 2(e)).

The vascular system is collateral and three arched at the midrib. The large central bundle is displaced to the abaxial area, and the two lateral bundles are smaller. The cells of the cortical parenchyma are isodiametric with phenolic content. At smaller bundles, the sheath has conspicuous non lignified cells extending to epidermis also with phenolic content. The vascular endings are simple or ramified, with one or more tracheids (Figure 2(f)). 

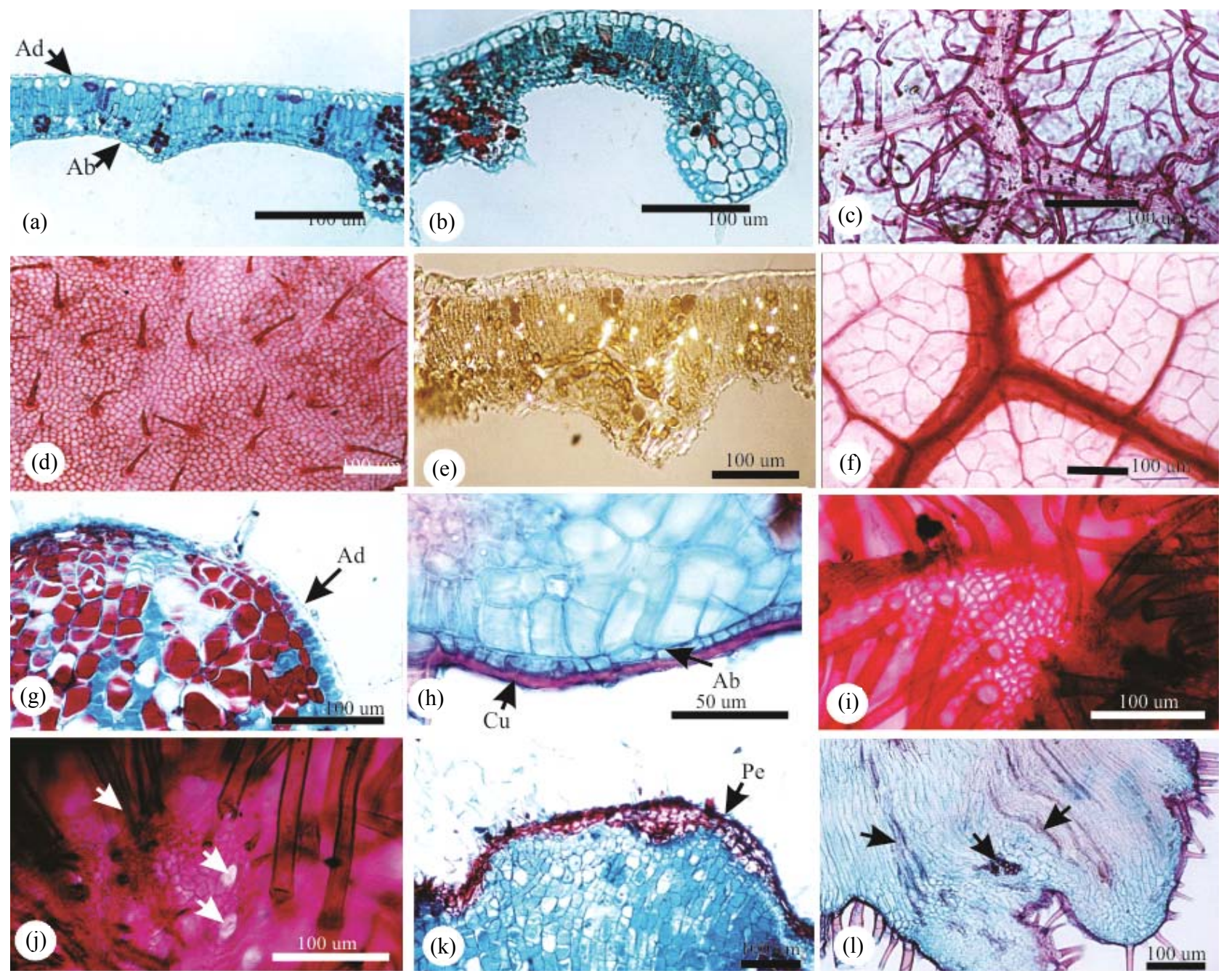

Figure 2. Anatomy of the non galled leaflets and galls of Caryocar brasiliense. (a), (b), (e) Transverse sections on mid position; (a) Leaflet lamina with uniseriate epidermis and 4 - 5 mesophyll layers differentiated in palisade and spongy parenchymas; (b) Leaflet margin occupied by non chlorophyllian parenchyma; (c), (d) Epidermal surfaces in frontal view; (c) Abaxial surface with abundant non glandular trichomes; (d) Adaxial surface with less abundant and shorter non glandular trichomes; (e) Mesophyll under polarized light evidencing crystals; (f) Venation pattern with terminal tracheids. $\mathrm{Ab}=\mathrm{abaxial}$, $\mathrm{Ad}=\mathbf{a d a x i a l}$. (j)-(l) Caryocar brasiliense. Anatomy of the leaflet globoid galls. (g)-(h), (k)-(l) Transverse sections. (g)-(h) Gall surface with uniseriate epidermis and homogeneous parenchyma. (g) Adaxial surface; (h) Abaxial surface with thick cuticle. (i), (j) Frontal view. (i) Adaxial surface with dense non glandular trichomes; (j) Abaxial surface with stomata (arrows) within the non glandular trichomes. (k) Instalation of periderm on gall adaxial surface; (l) Neoformed vascular bundles (arrows) on the abaxial portion of the gall. $\mathrm{Ab}=$ abaxial, $\mathrm{Ad}=$ adaxial, $\mathrm{Cu}=$ cuticle, $\mathrm{Pe}=$ periderm.

\subsection{Anatomical Features of Galls (GL)}

The epidermis of the GL is uniseriate (Figure 2(g) and (h)), with thick cuticle (Figure 2(h)). The cells of the abaxial surface are squared (Figure 2(g)), and flater (rectangular) (Figure 2(h)). In frontal view, the cells are small, with straight sometimes curved anticlinal cell walls (Figure 2(i)). The abaxial surface is similar to that of the healthy lamina. The stomata are located on the abaxial surface (Figure 2(j)) and non glandular trichomes are abundant on both leaflet surfaces (Figures 2(i)-(l)). Suberization may be observed in some gall spots, form- ing a 3 - 4 layered periderm (Figure 2(k)).

The parenchyma of GL is homogeneous, with some long and some lignified cells in the outer cortex (Figure 3(c)), and short and isodiametric cells in the inner one (Figure 3(a)). The larval chamber has $(0.41 \pm 0.08) \mathrm{mm}$ $\times(0.23 \pm 0.05) \mathrm{mm}$, and shelters one insect (Figures 1(e), 1(f), 3(a), 3(b)). The nutritive tissue has small polygonal cells with straight anticlinal walls (Figures 3(a)-(c)). The sclerenchyma is continuous and forms the border line between the outer and the inner cortices (Figure 3(a)), being discontinuous above the larval chamber. The scape 


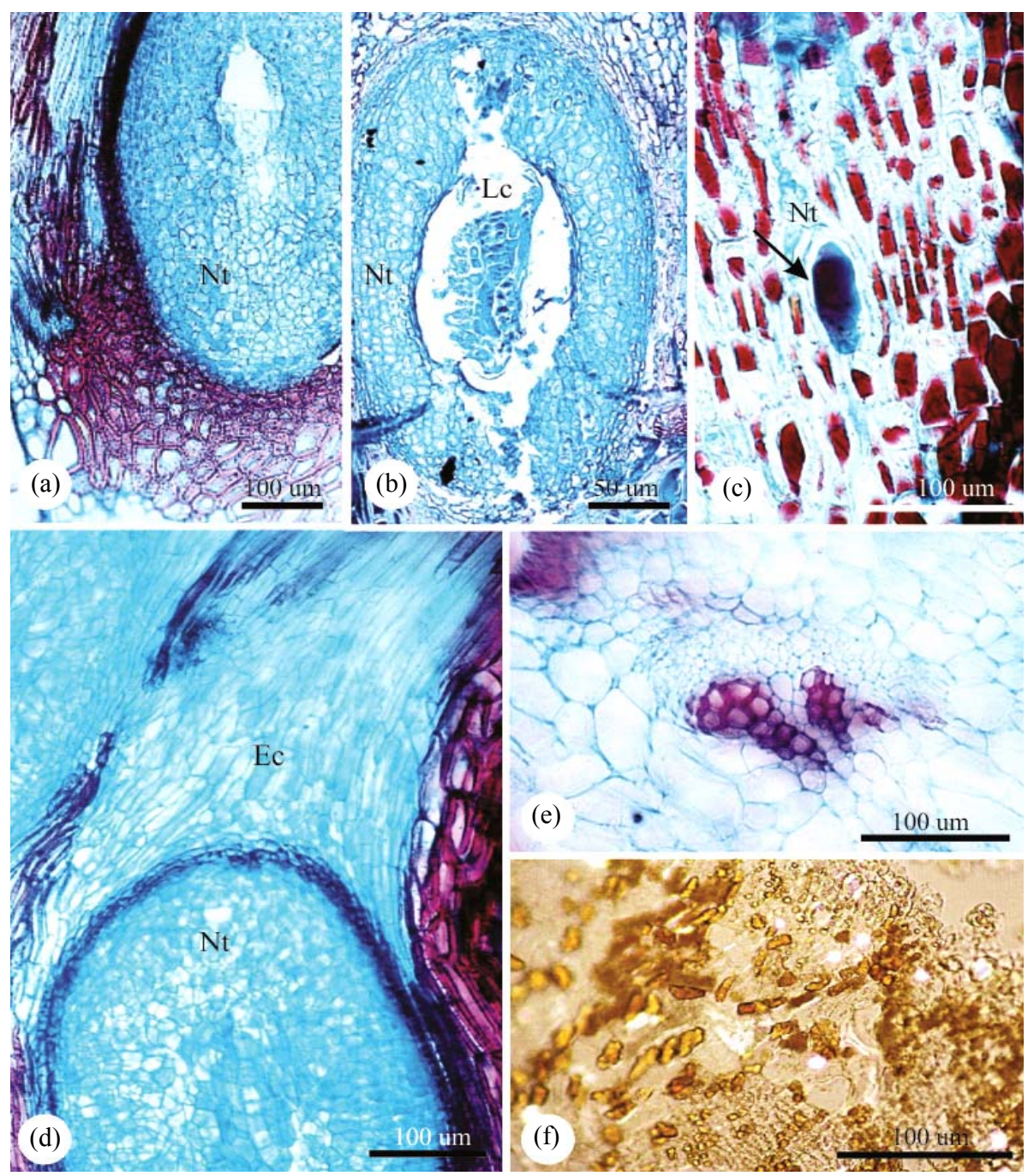

Figure 3. Anatomy of the leaflet globoid galls of Caryocar brasiliense. Transverse sections. (a) Nutritive tissue next to the larval chamber surrounded by schlerenchyma; (b) Gall inducing insect inside the larval chamber surrounded by nutritive tissue; (c) Detail of the elongated nutritive cells, and the inducer in initial stage of development; (d) Apical portion of the gall occupied by parenchymatic cells which will be destroyed by the digging of the escape channel; (e) Neoformed collateral vascular bundle; (f) Gall parenchyma with crystals. $\mathrm{Ec}=$ Escape channel, $\mathrm{Lc}=$ Larval chamber, $\mathrm{Nt}=$ Nutritive tissue.

channel is parenchymatic and is dig towards the adaxial gall surface (Figure 3(a)). Crystals are observed throughout gall cortex (Figure 3(f)), except at the escape channel.

The vascular bundles are distributed all over the cortex, external to the sclerenchyma, (Figures 2(l) and 3(e)), and more abundant at the outer cortex.

\section{Discussion}

The gall of Caryocar brasiliense develops in the leaflet lamina, because of the feeding action of a gall-inducing Hymenoptera. In general, this gall inducer exhibits a high degree of tissue specialization $[6,15,34]$, and is capable of significantly altering events of the host plant morphogenesis. The structure of this gall corresponds to the pat- tern described by Dreger-Jauffret \& Shorthouse [35] for Hymenopteran galls. They are round, covered by uniseriate epidermis or periderm, with one larval chamber, sheltering a single insect. Their final shape and structural complexity are related among other aspects to the feeding behavior and oviposition site.

In fact, the oviposition site, the final gall shape, and its structural complexity are relevant factors for many groups of galling insects [36]. They potentially parasitize all of the host plant organs [34] and even in a single organ, as the leaves, the galls can grow at different sites such as the margin, the internervural area, the midrib or the petiole [36]. In the galls of $C$. brasiliense, the host organ is the leaf, and the preferential site for oviposition is the margin between the medium portion and base of 
the lamina. At this site, the galling herbivore may intercept the flux of photoassimilates draining nutrients to its own development [37,38]. So, subtle differences in gall position can be critical [37] either for the gall inducers or for the host plant.

Even though gall induction over the ribs might facilitate the allocation of resources for the development of the gall or of the gall inducer [6,38], C. brasiliense galling herbivore seems not to benefit from this site. The leaf transition from sink to source condition begins at its apex towards the base up to the time the leaf is integrally an exporting organ [39]. So, gall induction in sites which remains longer in sink condition (from the center towards the base) may facilitate resources allocation either to gall development or gall-inducing insect maintenance. Also, the density of ribs did not show significant differences in leaflet areas, with the exception of the central portion of the lamina, where the density of ribs was smaller. So, the search for sites with larger contribution of nutrients seems not to be a fundamental behavior for the establishment of this gall. In spite of this, the choice of leaf margins as preferential sites for oviposition indicates low specialization of the galling herbivore taxa [40]. Further, the access to water in leaf tissues can be important once the gall inducers of $C$. brasiliense oviposit and develop at the leaflet margins.

That lower specialization, mentioned as the PriceRoininen hypothesis [40], seems to be compensated by the structure of C. brasiliense globoid galls. As a closed structure, it indicates a high adaptive value for protection of the gall inducer against its natural enemies and ensures an appropriate microenvironment [3]. According to Price [41] and Nyman [40], truly closed galls developed from marginal rolling up, and the closing of the tissues around the insect body can be interpreted as a morphological alteration that favors the escaping from parasitoids and predators, a premise also discussed by Cornell [42]. Even though the place of induction may be constant in some galls such as those of $C$. brasiliense, their mechanism of formation stays unknown [3]. The insects possibly control such formation, being, however, subjected to the adaptability and reactiveness of plant tissues $[4,43]$. The leaflet margin, the preferred site for oviposition in $C$. brasiliense, has appropriate tissue-objective for gall development, i.e., parenchyma. This is a very reactive tissue [43], which is reinforced by the aid of the neoformed trichomes and sclereids, water parenchyma and vascular bundles, sometimes, exclusively phloematic, and constitutes a favorable microenvironment for larval development $[44,45]$.

In fact, the leaflet globoid galls of $C$. brasiliense are characterized by a dense hairy surface which can directly influence in the formation and establishment not only of the gall inducer, but of the whole guild of associated insects. According to Stone et al. [46], the dense hairy surface, among other aspects, can reduce predation and parasitism. Also, the projection of the galls to the abaxial surface can also influence in the reduction of the attack of natural enemies, because, at this position, the galls become less visible. Further, a much less stressful microclimate is formed in this leaflet surface [7]. Nevertheless, against the positive effects of the reduction of the visibility is the grouping of the galls in C. brasiliense. That outstanding factor can increase the vulnerability to predators and parasitoids.

As emphasized by Cornell et al. [42] and Crespi \& Worobey [47], the evolutionary divergence of gall morphotypes might have been addressed by selection in function of the pressure imposed by the parasitoids and predators. This feature has a fundamental role in the definition of gall shapes and is directly related to anatomical features. In the globoid galls of $C$. brasiliense, the epidermis is uniseriate, with varying cuticle thickness. Such feature denotes the little plasticity of the dermal system under the influence of the gall inducer. However, the largest hairiness associated with the substitution of the epidermis for periderm in some gall sites indicates the expression of a character usually absent in leaf laminas. In general, trichomes redifferentiation in galls is considered the main feature related to the protection against natural enemies [48]. The formation of a suberized covering in galls was already observed in other systems such as Guarea macrophylla subsp. tuberculata (Meliaceae)Cecidomyiidae [7] and Copaifera langsdorffii (Leguminosae)-Cecidomyiidae $[8,18]$. The thickness of the cuticle, trichomes neoformation, and the eventual substitution of epidermis for periderm are characters that reinforce the hypothesis of the microenvironment $[3,49]$, which benefits gall inducing herbivores.

The ground system is thoroughly modified in function of gall differentiation. The mesophyll homogenization is a common process in insect galls and was registered by Souza et al. [50] for galls in Ficus microcarpa, Oliveira et al. [8] and Oliveira \& Isaias [9] for galls in Copaifera langsdorffii, and Oliveira et al. [15] for galls in Lonchocarpus muehlbergianus. The tissues of the mesophyll, in the globoid gall of C. brasiliense, stop acting as producers of photoassimilates, once chloroplasts do not differentiate, and assume the functions of storage of nutrients and water. Another outstanding characteristic in the studied galls is the presence of crystals, settled as rare in galls [51]. However, the crystals do not constitute an alteration caused by the galling herbivore, representing the maintenance of a characteristic common to the healthy tissues of the host plant, as was also registered by Rezende [32]. 
Internally to the covering tissue, there is the nutritive tissue whose cells are thin-walled, with dense cytoplasm, large nucleus and small and fragmented vacuoles. These cytological characteristics are similar to those of secretory cells $[15,19,52]$. The mechanical tissue, in medium position, becomes more lignified as the gall ripens, contributing to the reduction of the attack of predators and parasitoids. Even though the formation of lignified cells in galls has been commonly associated to protection [2,3], the lignification process has also been pointed out as a result of the antioxidant action of the phenolic compounds [53]. It also confers a secondary gain to the galling herbivores-host plant systems, namely, mechanical protection. The non lignified cells above the larval chamber, indicate the area where the escape channel will be formed.

The vascularization of the galls is a fundamental factor for their maintenance as potent drains of photoassimilates $[54,55]$. In the globoid galls of C. brasiliense, the vascularization is guaranteed by the differentiation of bundles located in the intermediate portions of the cortex. These bundles guarantees the supplying of photoassimilates for the development of the gall and of the galling herbivore $[15,40]$. In addition, vascular differentiation is a common phenomenon in insect galls $[8,9,13,44,56]$.

According to Price [57], the galling Hymenoptera have distinct degrees of specialization to their host plants and to the related gall structures. To this author, each species induce a unique gall type in a single host plant, which seems to be the case of the gall of C. brasiliense. Oliveira [27] attributed the induction of the round leaflet galls of C. brasiliense to a Eurytomidae (Hymenoptera), and Leite et al. [29] identified it as an Eurytoma (Hymenoptera: Chalcidoidea: Eurytomidae).

The galls of Hymenoptera present several degrees of complexity [38,57]. According to Rohfritsch [38], the galls of Hymenoptera: Cynipidae, for instance, have axial symmetry, a single larval chamber, and concentric tissues disposed around the chamber. Such a pattern resembles the one observed in the leaflet globoid gall of $C$. brasiliense. The same author points out that the galls of Hymenoptera: Chalcidoidea has a nutritive tissue, which is in direct contact with a sclerenchymatic layer, and is totally consumed by the larva, a feature observed in mature galls of $C$. brasiliense. Other features such as the total consumption of the nutritive tissue in gall maturity $[12,16]$, the differentiation of local periderm [56,58], or even of trichomes in galls of Eurytoma sp. [58] were also observed in the globoid gall of $C$. brasiliense.

In comparison to the patterns described in literature, morphological and anatomical characters of the globoid leaflet gall of C. brasiliense, such as its marginal position, the fact of being a truly closed gall, and the presence of a typical nutritive tissue involved by sclerenchyma, approximates it from the pattern proposed for Hymenopteran galls.

The morphogenesis of this gall demonstrates that, at least for this gall inducer species, the parenchymatic nature of the site of oviposition and development of the gall was more important than the interception of nutrients.

\section{Acknowledgements}

The authors thank CNPq, CAPES and FAPEMIG for the scholarships, and financial support for the development of this research.

\section{REFERENCES}

[1] M. S. Mani, "Introduction to Cecidology," In: J. D. Shorthouse and O. Rohfritsch, Eds., Biology of Insect Induced Galls, Oxford University, Oxford, 1992.

[2] J. Meyer and H. J. Maresquelle, "Anatomie des Galles," Gebrüder Borntraeger, Berlin, 1983.

[3] G. N. Stone and K. Schönrogge, "The Adaptative Significance of Insect Gall Morphology," Trends in Ecology and Evolution, Vo1. 8, 2003, pp. 512-522.

[4] A. Raman, "Insect-Induced Plant Galls of India: Unresolved Questions," Current Science, Vol. 92, No. 6, 2007, pp. 748-757.

[5] L.A. Rey, "Developmental Morphology of Two Types of Hymenopterous Galls," In: J. D. Shorthouse and O. Rohfritsch, Eds., Biology of Insect Induced Galls, Oxford University, Oxford, 1992

[6] M. S. Mani, "Ecology of Plant Galls," The Hague, Dr. Junk Publishers, 1964.

[7] J. E. Kraus, H. C. Sugiura and S. Cutrupi, "Morfologia e Ontogenia em Galhas Entomógenas de Guarea macrophylla subsp. tuberculata (Meliaceae)," Fitopatologia Brasileira, Vol. 21, No. 3, 1996, pp. 349-356.

[8] D. C. Oliveira, M. M. Drummond, A. S. F. P. Moreira, G. L. G. Soares and R. M. S. Isaias, "Potencialidades Morfogênicas de Copaifera langsdorffii Desf. (Fabaceae): Super Hospedeira de Herbívoros Galhadores," Revista de Biologia Neotropical, Vol. 5, 2008, pp. 31-39.

[9] D. C. Oliveira and R. M. S. Isaias, "Redifferentiation of Leaflet Tissues during Midrib Gall Development in Copaifera langsdorffii (Fabaceae)," South African Journal of Botany, Vol. 76, No. 2, 2010, pp. 239-248. doi:10.1016/j.sajb.2009.10.011

[10] D. C. Oliveira and R. M. S. Isaias, "Influence of Leaflet Age in Anatomy and Possible Adaptive Values of the Midrib Gall of Copaifera langsdorffii (Fabaceae: Caesalpinioideae)," Revista de Biología Tropical, Vol. 57, 2009, pp. 293-302.

[11] R. M. S. Isaias, G. L. G. Soares, J. C. S. Christiano and S. J. M. R. Gonçalves, "Análise Comparativa Entre as Defesas Mecânicas e Químicas de Aspidosperma australe Müell. Arg. e Aspidosperma cylindrocarpon Müell. Arg. 
(Apocynaceae) Contra Herbivoria," Floresta e Ambiente, Vol. 7, No. 1, 2000, pp. 11-18.

[12] J. E. Kraus, M. Arduin and M. Venturelli, "Anatomy and Ontogenesis of Hymenopteran Leaf Galls of Struthanthus vulgaris Mart. Loranthaceae)," Revista Brasileira de Botânica, Vol. 25, No. 4, 2002, pp. 449-458.

[13] S. J. M. R. Gonçalves, R. M. S. Isaias, F. H. A. Vale and G. W. Fernandes, "Sexual Dimorphism of Pseudotectococcus rolliniae Hodgson \& Gonçalves 2004 (Hemiptera Coccoidea Eriococcidae) Influences Gall Morphology on Rollinia laurifolia Schltdl. (Annonaceae)," Tropical Zoology, Vol. 18, 2005, pp. 161-169.

[14] D. C. Oliveira, J. C. S. Christiano, G. L. G. Soares and R. M. S. Isaias, "Reações de Defesas Químicas e Estruturais de Lonchocarpus muehlbergianus Hassl. (Fabaceae) à ação do Galhador Euphalerus ostreoides Crawf. (Hemiptera: Psyllidae)," Revista Brasileira de Botânica, Vol. 29, No. 4, 2006, pp. 657-667.

[15] R. Bronner, "The Role of Nutritive Cells in the Nutrition of Cynipids and Cecidomyiids," In: J. D. Shorthouse and O. Rohfritsch, Eds., Biology of Insect Induced Galls, Oxford University, Oxford, 1992.

[16] J. E. Kraus and M. Tanoue, "Morpho-Ontogenetic Aspects of Entomogenous Galls in Roots of Cattleya guttata (Orchidaceae)," Lindleyana, Vol. 14, 1999, pp. 204-213.

[17] D. C. Oliveira and R. M. S. Isaias, "Cytological and Histochemical Gradients Induced by a Sucking Insect in Galls of Aspidosperma australe Arg. Muell (Apocynaceae)," Plant Science, Vol. 178, No. 4, 2010, pp. 350-358. doi:10.1016/j.plantsci.2010.02.002

[18] D. C. Oliveira, T. A. Magalhães, R. G. S. Carneiro, M. N. Alvim and R. M. S. Isaias, "Do Cecidomyiidae Galls of Aspidosperma spruceanum (Apocynaceae) Fit the PreEstablished Cytological and Histochemical Patterns?" Protoplasma, Vol. 242, No. 1-4, 2010, pp. 81-93. doi:10.1007/s00709-010-0128-6

[19] D. C. Oliveira, T. A. Magalhães, R. G. S. Carneiro and R. M. S. Isaias, "Cytological and Histochemical Gradients on Two Copaifera langsdorffii Desf. (Fabaceae)-Cecidomyiidae Gall Systems," Protoplasma, Vol. 248, No. 4, 2011, pp. 829-837. doi:10.1007/s00709-010-0258-x

[20] G. W. Fernandes, L. M. Araújo, M. A. Carneiro, T. G. Cornelissen, M. C. Barcelos-Greco, A. C. F. Lara and S. Ribeiro, "Padrões de Riqueza de Insetos em Gradientes Altitudinais na Serra do Cipó, Minas Gerais," In: L. L. Leite and C. H. Saito, Eds., Contribuição ao Conhecimento Ecológico do Cerrado, Universidade de Brasília, Brasília, 1997.

[21] G. W. Fernandes, G. R. Julião, R. C. Araújo, J. A. Lombardi, D. Negreiros and M. A. A. Carneiro, "Distribution and Morphology of Insect Galls of the Rio Doce Valley, Brazil," Naturalia, Vol. 26, 2001, pp. 221-224.

[22] S. J. Gonçalves-Alvim and G. W. Fernandes, "Biodiversity of Galling Insects: Historical, Community and Habitat Effects in Four Neotropical Savannas," Biodiversity and Conservation, Vol. 10, No. 1, 2001, pp. 79-98. doi:10.1023/A:1016602213305

[23] V. C. Maia and G. W. Fernandes, "Insect Galls from
Serra de São José (Tiradentes, MG, Brazil)," Brazilian Journal of Biology, Vol. 64, 2004, pp.423-445. doi:10.1590/S1519-69842004000300007

[24] J. C. Oliveira and V. C. Maia, "Ocorrência e Caracterização de Galhas de Insetos na Restinga de Grumari (Rio de Janeiro, RJ, Brasil)," Arquivos do Museu Nacional, Rio de Janeiro, Vol. 63, No. 4, 2005, pp. 669-675.

[25] G. T. Prance, "The Genus Caryocar L. (Caryocaraceae): an Underexploited Tropical Resource," Advances in Economic Botany, Vol. 8, 1990, pp. 177-188.

[26] G. T. Prance and M. F. Silva, "Caryocaraceae," Hafner, New York, (Flora Neotropica, Monograph No. 12), 1973.

[27] P. S. Oliveira, "The Ecological Function of Extrafloral Nectaries: Herbivore Deterrence by Visiting Ants and Reproductive Output in Caryocar brasiliense (Caryocaraceae)," Functional Ecology, Vol. 11, No. 3, 1997, pp. 323-330. doi:10.1046/j.1365-2435.1997.00087.x

[28] P. S. Oliveira and A. V. L. Freitas, "Ant-Plant-Herbivore Interactions in the Neotropical Cerrado Savanna," Naturwissenschaften, Vol. 91, No. 12, 2004, pp. 557-570. doi:10.1007/s00114-004-0585-x

[29] G. L. D. Leite, R. V. S. Veloso, A. C. Redoan, P. S. N. Lopes and M. M. L. Machado, “Artrópodes (Arthropoda) Associados a Mudas de Pequizeiro Caryocar brasiliense Cambess. (Caryocaraceae)," Arquivos do Instituto Biológico, Vol. 73, 2006, pp. 365-370.

[30] M. V. Urso-Guimarães, C. Scareli-Santos and A. C. Bonifácio-Silva, "Occurence and Characterization of Entomogenous Galls in Plants from Natural Vegetation Areas in Delfinópolis, MG, Brazil," Brazilian Journal of Biology, Vol. 63, No. 4, 2003, pp. 705-715.

[31] D. A. Johansen, "Plant Microtechnique," McGraw-Hill Book Co. Inc., New York, 1940.

[32] M. H. Rezende, "Anatomia dos Órgãos Vegetativos, da flor e Estruturas Secretoras de Caryocar brasiliense Camb. (Caryocaraceae)," Tese de Doutorado, Universidade de São Paulo, Instituto de Biociências, São Paulo, 1998.

[33] J. E. Kraus and M. Arduin, "Manual Básico de Métodos em Morfologia Vegetal,” Seropédica, EDUR, 1997.

[34] J. D. Shorthouse and O. Rohfritsch, "Biology of Insect Induced Galls," Oxford University, Oxford, 1992.

[35] F. Dreger-Jauffret and J. D. Shorthouse, "Diversity of Gall-Inducing Insects and Their Galls," In: J. D. Shorthouse and O. Rohfritsch, Eds., Biology of Insect Induced Galls, Oxford University, Oxford 1992.

[36] M. Inbar, M. Wink and D. Wool, "The Evolution of Host Plant Manipulation by Insects: Molecular and Ecological Evidence from Gall-Forming Aphids on Pistacia," Molecular Phylogenetics and Evolution, Vol. 32, No. 2, 2004, pp. 504-511. doi:10.1016/j.ympev.2004.01.006

[37] T. G. Whitham, "Territorial Behaviour of Pemphigus Gall Aphids," Nature, Vol. 279, No. 5711, 1979, pp. 324-325. doi:10.1038/279324a0

[38] O. Rohfritsch, "Patterns in Gall Development," In: J. D. Shorthouse and O. Rohfritsch, Eds., Biology of Insect In- 
duced Galls, Oxford University, Oxford, 1992.

[39] L. Taiz and E. Zeiger, "Fisiologia Vegetal," 3rd Edition, Artmed, Porto Alegre, 2004.

[40] T. Nyman, "Phylogeny and Ecological Evolution of GallInducing Sawflies (Hymenoptera: Tenthredinidae)," $\mathrm{PhD}$ Dissertations in Biology, University of Joensuu. No. 6, 2000.

[41] P. W. Price, "Evolution and Ecology of Gall-Inducing Sawflies," In: J. D. Shorthouse and O. Rohfritsch, Eds., Biology of Insect Induced Galls, Oxford University, Oxford, 1992.

[42] H. V. Cornell, "The Secondary Chemistry and Complex Morphology of Galls Formed by the Cynipinae. Why and How?" American Midland Naturalist, Vol. 110, No. 2, 1983, pp. 225-234. doi: $10.2307 / 2425263$

[43] A. E. Weis, R. Walton and C. L. Crego, "Reactive Plant Tissue Sites and the Population Biology of Gall Makers," Annual Review of Entomology, Vol. 33, 1988, pp. 467486. doi:10.1146/annurev.en.33.010188.002343

[44] R. M. S. Isaias, "Galhas Entomógenas em Machaerium (Leguminosae-Papilionoidae): Anatomia e Histoquímica," Tese de doutorado, Universidade de São Paulo, São Paulo, 1998.

[45] C. Vecchi, "Reações Diferenciais a Herbívoros Galhadores em Espécies de Melastomataceae," Tese de Doutorado, Universidade de São Paulo, São Paulo, 2004.

[46] G. N. Stone, K. Schönrogge, R. J. Atkinson, D. Bellido and J. Pujade-Villar, "The Population Biology of Oak Gall Wasps (Hymenoptera: Cynipidae)," Annual Review of Entomology, Vol. 47, 2002, pp. 633-668. doi:10.1146/annurev.ento.47.091201.145247

[47] B. J. Crespi and M. Worobey, "Comparative Analysis of Gall Morphology in Australian Gall Thrips: The Evolution of Extended Phenotypes," Evolution: International Journal of Organic Evolution, Vol. 52, 1998, pp. 16861696. doi: $10.2307 / 2411341$

[48] R. Bailey, K. Schönrogge, J. M. Cook, G. Melika, G. Csóka, C. Thuróczy and G. N. Stone, "Host Niches and Defensive Phenotypes Structure Parasitoid Wasp Communities," PLoS Biology, Vol. 7, No. 5, 2009, pp. 1-12. doi:10.1371/journal.pbio.1000179
[49] P. W. Price, G. W. Fernandes and G. L. Waring, “Adaptive Nature of Insect Galls," Environmental Entomology, Vol. 16, No. 1, 1987, pp. 15-24.

[50] S. C. Souza, J. E. Kraus, R. M. S. Isaias and L. J. Neves, "Anatomical and Ultrastructural Aspects in Ficus microcarpa L. f. (Moraceae) Induced by Gynaikothrips ficorum Marchal (Thysanoptera)," Acta Botanica Brasilica, Vol. 14, No. 1, 2000, pp. 57-69.

[51] G. W. Fernandes, R. W. Preszler and J. N. Grim, "The Occurrence of Crystals in a Cynipid Leaf Gall on Quercus turbinella," Beitraege zur Biologie der Pflanzen, Vol. 65, No. 3, 1990, pp. 377-383.

[52] A. Fahn, "Structure and Function of Secretory Cells," Advances in Botanical Research, Vol. 31, 2000, pp. 37-75. doi:10.1016/S0065-2296(00)31006-0

[53] G. L. G. Soares, R. M. S. Isaias, S. J. M. R. Gonçalves and J. C. S. Christiano, "Alterações Químicas Induzidas por Coccídeos (Coccoidea, Brachyscelidae) em folhas de Rollinia laurifolia Schdtl. (Annonaceae)," Revista Brasileira de Zoociências, Vol. 2, 2000, pp. 103-133.

[54] K. C. Larson and T. G. Whitham, "Manipulation of Food Resources by a Gall-Forming Aphid: The Physiology of Sink-Source Interactions," Oecologia, Vol. 88, No. 1, 1991, pp. 15-21. doi:10.1007/BF00328398

[55] S. E. Hartley, "The Chemical Composition of Plant Galls: Are Levels of Nutrients and Secondary Compounds Controlled by the Gall-Former?" Oecologia, Vol. 113, No. 4, 1998, pp. 492-501. doi:10.1007/s004420050401

[56] J. E. Kraus, J. A. Solórzano Filho, M. Arduin and R. M. S. Isaias, "Respostas Morfogenéticas de Plantas Brasileiras a Insetos Galhadores," In: R. Fortunato and N. Bacigalupo, Eds., Proceedings of the VI Congresso Latinoamericano de Botânica, Mar del Plata, Argentina, 1994.

[57] P. W. Price, "Adaptive Radiation of Gall-Inducing Insects," Basic and Applied Ecology, Vol. 6, 2005, pp. 413421. doi:10.1016/j.baae.2005.07.002

[58] H. B. Krishnan and V. R. Fransceschi, "Anatomy of Some Leaf Galls of Rosa woodsii (Rosaceae)," American Journal of Botany, Vol. 75, 1998, pp. 369-376. doi: $10.2307 / 2443984$ 